\title{
Megafauna biogeography explains plant functional trait variability in the tropics
}

\author{
Vinicius L. Dantas' ${ }^{\prime}(\mathbb{D})$ \& Juli G.Pausas?
}

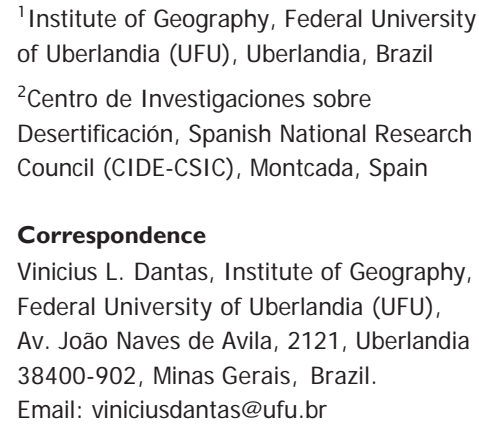

\begin{abstract}
Aim: Biomes can diverge substantially in plant functional traits and disturbance regimens among regions. Given that Neotropical and Afrotropical regions have contrasting histories of the megafauna (because of the Holocene megafaunal extinction in the Neotropics), we hypothesize that they should harbour plants with different traits in relationship to herbivory and fire, especially in savannas. We predicted that herbivory resistance traits should be more prominent in Afrotropical savanna plants and fire resistance in Neotropical savanna plants.
\end{abstract}

Location: Tropics.

Time period: Not applicable.

Major taxa studied: Angiosperms (woody).

Methods: We compiled data for five key plant functional traits (wood density, specific leaf area, maximum tree height, spinescence and proportion of geoxyles) for forest and savanna woody species from the two distant regions (Afrotropics and Neotropics). We related these data to climate, soil and fire variables and tested predictions for megafauna selection.

Results: Spines and high wood density were more common among Afrotropical than Neotropical savanna species and species from the two forests. Moreover, the Neotropical savanna region contained more geoxyles than the Afrotropical savanna region. Finally, Afrotropical species were taller than Neotropical species. These differences were consistent with our predictions for trait selection by the megafauna, and these patterns did not change when considering climate, soil and fire regimens in the models.

Main conclusions: Our results highlight the great potential of these traits for summarizing disturbance strategy axes in tropical woody species and suggest that global variation in plant traits is unlikely to be understood fully without consideration of historical factors, especially the direct and indirect impacts of megafauna.

KEY WOR D S

cerrado, fire, forest, functional traits, herbivory, megafauna, savanna, wood density 


\section{INTRODUCTION}

Biomes are macroecological systems resulting from complex selective and demographic processes. They are easily recognized from the size, relative dominance and spatial arrangement of particular plant growth forms that result in characteristic vegetation physiognomies. Notwithstanding, plant assemblages may exhibit substantial differences biogeographically within a biome, including differences in the adaptive strategies and functional traits of the dominating woody plants (Dantas \& Pausas, 2013; Rogers, Soja, Goulden, \& Randerson, 2015). Given that traits often regulate the way in which plants interact with the environment, these idiosyncrasies impose challenges to the development of general predictive models for biome-scale responses to global changes (Archibald et al., 2018; Lehmann et al., 2014; Moncrieff, Bond, \& Higgins, 2016; Rogers et al., 2015). An understanding of these differences would provide insights into the variety of ways in which climate, soil and disturbance regimens interact to control biome distribution in space and time.

Forest and savanna biomes predominate in tropical latitudes (Dinerstein et al., 2017). These biomes are assembled by different processes: savannas are maintained by disturbance (Bond, 2005; Dantas, Hirota, Oliveira, \& Pausas, 2016), whereas forests are regulated mainly by competition (Cardoso et al., 2019; Dantas, Batalha, \& Pausas, 2013). Nonetheless, the same biome may exhibit substantial differences geographically in ecology and history. One of the most outstanding of these differences relates to the extinction of megafauna outside Africa (e.g., in the Neotropics, c. $10 \mathrm{kyr}$ ), modulating the dominant disturbance regimen, nutrient cycling and plant strategies in savannas (Dantas \& Pausas, 2013; Doughty, 2017). In fact, even before this event, the megafauna of the two regions already differed in number and composition (Owen-Smith, 2013). For instance, the present and historical lack of megagrazers to control grass biomass and promote herbivory-maintained savannas in the Neotropics might have favoured more savannas maintained by high-intensity surface fires, resulting in the dominance of species that allocate resources to shoot insulation and resprouting (Dantas et al., 2016; Dantas \& Pausas, 2013; Tomlinson et al., 2012). In contrast, allocation of resources for high rates of vertical growth is more important in Afrotropical savannas to avoid crown damage by both low-intensity (grazer-controlled) surface fires and browsing (Archibald \& Bond, 2003; Dantas \& Pausas, 2013). Many studies are also showing that plants with spines and densely branched crowns are favoured and even evolved in response to megaherbivores in African savannas (Charles-Dominique et al., 2016; Staver, Bond, Cramer, \& Wakeling, 2012). In contrast, plants with specialized woody bud-bearing underground structures (geoxyles or "underground trees") are also favoured and evolved in fire-maintained ecosystems where herbivory is low (e.g., wet regions; Maurin et al., 2014; Pausas, Lamont, Paula, Appezzato-da-Glória, \& Fidelis, 2018). The extent to which these patterns scale up to intercontinental scales owing to the differential histories of the megafauna is not yet known.

For a long time, ecologists have been searching for a set of easily measurable traits to represent the leading axes of trait strategy for global comparisons. Among the most studied traits for woody plants are maximum tree height (HMax), specific leaf area (SLA) and woody density (WD). Variation in these traits is generally understood to result from the climate and soil (Liu et al., 2019; Maire et al., 2015; Moles et al., 2009; Ordoñez et al., 2009; Quesada et al., 2012; Reich, Wright, \& Lusk, 2007; Swenson \& Enquist, 2007). However, the explained variance is often modest and context dependent, suggesting that other drivers play an important role. Wood density is positively related to the mechanical resistance of stems and branches, survival rates and shade tolerance and negatively related to the water content of stems, hydraulic conductivity and resprouting capacity (Chave et al., 2009; Hietz, Rosner, Hietz-Seifert, \& Wright, 2017). A high WD would provide mechanical stability not only to forest trees with large and tall crowns, but also to savanna plants exposed to breakage by large browsers (e.g., elephants). Another relevant trait is SLA, which is related to resource strategy (e.g., shade tolerance) and disturbance resistance (flammability and palatability; Pausas, Keeley, \& Schwilk, 2017; Poorter, Ninemets, Poorter, Wright, \& Villar, 2009). Leaves with high SLA are inexpensive, short lived, soft, nitrogen rich, shade tolerant, flammable, drought and herbivory sensitive and have low tissue density and high photosynthetic rates, whereas leaves with low SLA have the opposite attributes (Poorter et al., 2009; Westoby, Falster, Moles, Vesk, \& Wright, 2002). The former attributes are typically associated with shaded, resource-rich and infrequently disturbed environments, such as forest, whereas the latter are found in frequently disturbed sunny areas (Dantas et al., 2013; Poorter et al., 2009). Whether this trait is predominantly controlled by herbivory, fire or resources is unclear. Finally, a high HMax is adaptive in light-limited environments, such as tropical forest (Moles et al., 2009; Westoby et al., 2002). Given that tall stems are costly in terms of production, maintenance and water transport (Liu et al., 2019; Westoby et al., 2002), growing very tall should be less adaptive where light is not limiting, especially in nutrient-poor soils, such as those of Neotropical savannas (Dantas \& Pausas, 2013; Moles et al., 2009). In these ecosystems, high-intensity surface fires make allocation to tissue and resource protection (e.g., bark thickness, underground organs) more important (Dantas \& Pausas, 2013; Pausas et al., 2018; Tomlinson et al., 2012). Moreover, even in herbivory-controlled ecosystems, plants should maintain tree height slightly above the browsing trap in order to be able to allocate carbon to other defensive traits. The HMax is also correlated positively with fruit size (Wright et al., 2007), and the historically lower richness of browser species in South America (Owen-Smith, 2013), combined with the effects of the extinction of megafauna from the region, might have led to a lower number of tall, large-fruited species (Doughty, Wolf, et al., 2016; Mack, 1993). The extent to which the history of megafauna affects the geographical patterns of these trait attributes has not yet been evaluated rigorously.

In this study, we evaluated the hypothesis that differences in plant functional traits among biogeographical regions could be explained by a different historical distribution, abundance and composition of megafauna. Megaherbivorous mammals have existed in both the Neotropics and Afrotropics for tens of millions of years and were present during 
the origin of tropical savannas in both regions (Pennington \& Hughes, 2014). Although the extinction of these animals from South America in the Pleistocene-Early Holocene might be too recent to produce substantial evolutionary changes in woody species (c. 100-200 tree generations), it could have been sufficient to produce changes in species and biome distribution and even to trigger plant extinctions (Doughty, Wolf, et al., 2016; Guimarães, Galetti, \& J ordano, 2008). Recent evidence suggests that alternative savanna states, maintained by either fire or megaherbivores, do exist in Africa (Dantas et al., 2016; Pausas \& Bond, 2020; Pellegrini, Pringle, Govender, \& Hedin, 2016). If these ecosystem states also existed in the Neotropics, the extinction of megafauna is likely to have produced the retraction of herbivory-maintained savanna states and their species. Moreover, even before the extinction of megafauna, the number of species of megafauna, especially grazers and animals with body mass $10-1,000 \mathrm{~kg}$, was already lower in the Neotropics (Owen-Smith, 2013).

To test our hypothesis, we compiled data on spinescence (presence/absence), HMax (in metres), SLA (in square millimetres per milligram), and WD (in grams per cubic centimetre) for Afrotropical and Neotropical savanna and forest species (Dantas \& Pausas, 2020; data sources are available in the Appendix and methodological details in the Supporting Information Appendices S1 and S2 and Table S2.1). We also compiled data on the proportion of geoxylic species in relationship to the total number of woody species for two large savanna-dominated Neotropical (Brazilian Cerrado) and Afrotropical (southern Africa) regions (for details, see Supporting Information Appendix S1). For the continuous traits, we also evaluated the extent to which climate, soil and fire explained biogeographical differences between and within biomes, because these traits are often considered to be explained by these habitat variables.

We expected savannas, but not forest, from different continents to contrast in disturbance strategy, because of different histories of megafauna. We also expected Afrotropical savanna species to be differentiated from the remainina savanna and forest species bv presenting more adaptations to herbivory, such as spines and a high WD (these traits are fundamental for avoiding tissue damage by browsers). Neotropical savanna species, in contrast, were expected to be more specialized in resisting high-intensity surface fires (attributable to higher grass productivity/lower grazer consumption; Dantas \& Pausas, 2013) In a nutrient-poor background (soll leachıng and more fire-mediated nutrient losses). Thus, in addition to the well-known differences in the fire-escape strategy of trees and shrubs (i.e., higher and lower allocation to bark and height growth respectively; Dantas woody species and an extreme resource conservative strategy (shorter stems, lower SLA and WD) in Neotropical savanna species. This strategy would be useful for saving and protecting resources for post-fire resprouting. In forest, we predicted light competition to select for the tallest trees, but given that large-fruited plants tend to be taller and to depend on large herbivores for dispersal, we predicted African plants to be taller than Neotropical ones (that lack megaherbivores). This effect should be weaker in savanna woody species, because resprouting is more important than seeding as a strategy for regeneration.

\section{TRAIT DIFFERENCES ARE CONSISTENT WITH AN EFFEC T OF MEGAFAUNA}

To compare SLA, WD and HMax between biomes and continents, we used a general linear mixed-effect model, with trait as the response variable, biome, continent and their interaction as fixed effects, and reference source as random effect, followed by Tukey's post-hoc comparison. The best model was selected using stepwise backward variable selection based on the Akaike information criterion (AI C; for details, seeSupporting I nformation AppendixS1).

The final analyses included 339 woody species for SLA, 1,945 species for WD and 1,346 species for maximum tree height (for more details, see Table 1). We found that all three continuous traits were significantly different between biomes, and only maximum tree height also differed consistently between biogeographical regions (Table 2; Figure 1a-c); that is, Afrotropical species were significantly taller than Neotropical species. The SLA was lower in savanna compared with forest (Figure 1a; Table 2; Supporting Information Appendix S2 and Table S2.2), in the two continents (Figure 1a). Forests from the two regions had similar WD values and differed significantly from both savannas, although in different ways (significant biome-region interaction; Table 2; Supporting Information Table S2.2): Afrotropical savanna species had the highest values (higher than the forests), whereas Neotropical savanna species had the lowest (lower than the forests; Figures 1 and 2). For HMax,

TA B L E 1 Number of species per trait, biome and biogeographical region (Afrotropical and Neotropical) included in

\begin{tabular}{|c|c|c|c|}
\hline \multirow[b]{2}{*}{ Trait } & \multirow[b]{2}{*}{ Biome } & \multicolumn{2}{|c|}{ Number of species } \\
\hline & & Neotropical & Afrotropical \\
\hline \multirow[t]{2}{*}{$\mathrm{SLA}\left(\mathrm{mm}^{2} / \mathrm{mg}\right)$} & Savanna & 117 & 86 \\
\hline & Forest & 104 & 32 \\
\hline \multirow[t]{2}{*}{$W D\left(\mathrm{~g} / \mathrm{cm}^{3}\right)$} & Savanna & 77 & 80 \\
\hline & Forest & 1,408 & 380 \\
\hline \multirow[t]{2}{*}{$\mathrm{HMax}(\mathrm{m})$} & Savanna & 310 & 105 \\
\hline & Forest & 561 & 370 \\
\hline \multirow{2}{*}{$\begin{array}{l}\text { Spinescence } \\
\text { (yes/no) }\end{array}$} & Savanna & $216(9)$ & $102(35)$ \\
\hline & Forest & 788 (32) & $305(15)$ \\
\hline \multirow[t]{2}{*}{ Total } & Savanna & 370 & 106 \\
\hline & Forest & 1,720 & 395 \\
\hline Geyexy/iøplants* & & 3,599 (376) & $1,400(53)$ \\
\hline
\end{tabular}

Note: Numbers in parentheses are the numbers of spine-bearing or geoxylic suffrutex species; total refers to the common species among traits, excluding geoxyles, because the list of all species provided by Maurin et al. (2014; our data source for Africa) was not available to check the overlaps.

*Data for geoxyles are at the geographical (savanna) region scale, rather than the real biome scale (African Zambezian versus Neotropical Brazillian Cerrado regions; see Supporting Information Appendix S1). Abbreviations: HMax, maximum tree height; SLA, specific leaf area; WD, wood density. 
TA B L E 2 Results of linear mixed-effect models for plant functional traits of tropical savanna and forest species against resource availability, fire regimen, biome and biogeographical region (Afrotropical and Neotropical)

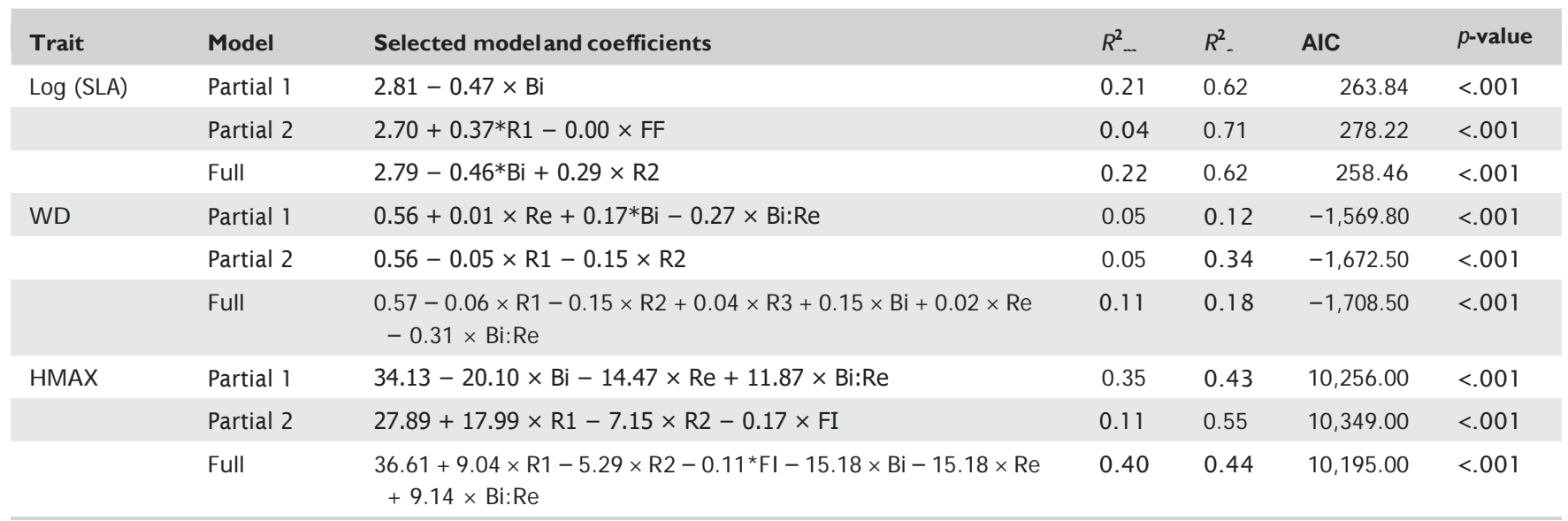

Note: For each trait, we used three starting models (Model), one partial model (Partial 1) including biome (Bi), biogeographical region (Re) and their interaction (Bi:Re); a second partial model (Partial 2) including only resource availability- and fire-related variables; and a third model (Full) including variables from both Partial 1 and Partial 2. Random effects are the reference sources for trait data.

Abbreviations: AIC, Akaike information criterion; FF, fire frequency (using fire count per area as a proxy); FI, fire intensity (average fire radiative power); $\mathrm{HMax}_{2}$ maximum tree height (in metres); R1-R3, principal components analyşis resource-related axes 1-3 (Supporting Information Table S2.3); $R^{2}$, conditional $R^{2}$ (full model: fixed and random effects); $R^{2}$, marginal $R^{2}$ (fixed effects); SLA, specific leaf area (in square millimetres per milligram); WD, wood density (in grams per cubic centimetre).
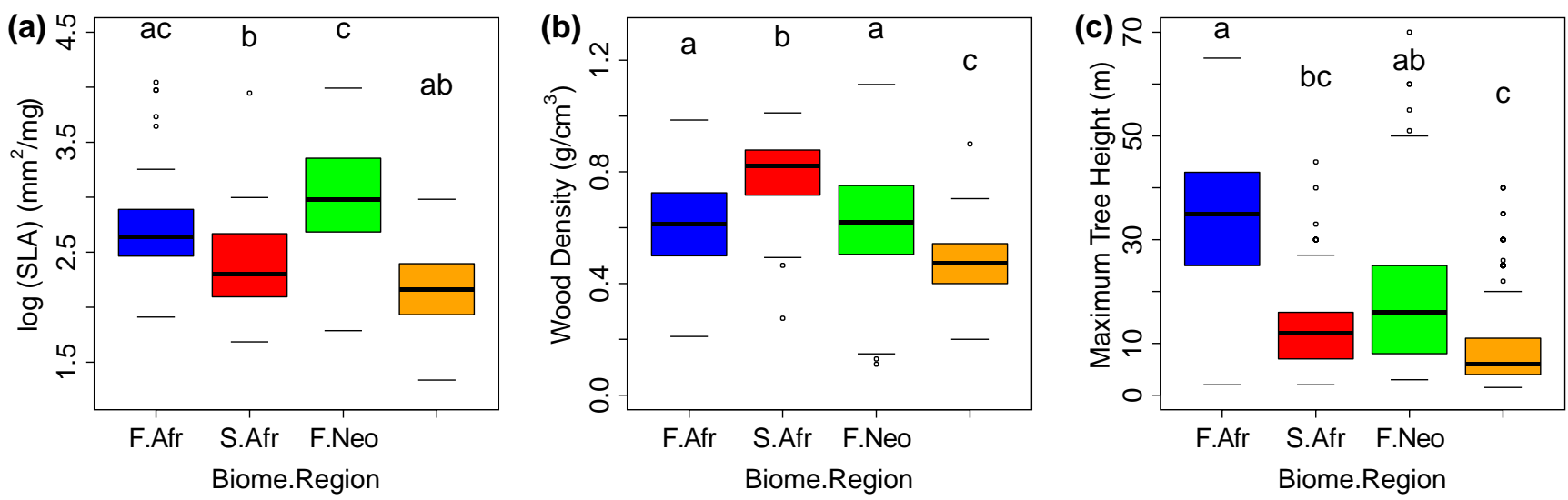

FI G U R E 1 Distribution of trait values between biome ( $F=$ forest; $S=$ savanna) and biogeographical region (Afr = Afrotropical; Neo = Neotropical). Different letters indicate significant (and same letter non-significant) pairwise difference between estimated marginal means (see Table 3) [Colour figure can be viewed at wileyonlinelibrary.com]

forest species tended to be taller than savanna species within the two regions, but Neotropical forest species had similar HMax values compared with Afrotropical savanna and forest species.

To assess how these traits covaried and separated species by biome and continent in functional trait space, we carried out a principal components analysis (PCA) including only those species with a full trait set (that is, SLA, WD and HMax information; 154 species). We found a full functional trait set for 46 forest (17 Afrotropical and 29 Neotropical) and 108 savanna (66 Afrotropical and 42 Neotropical) species. The first principal component separated forests (positive axis values) from savannas (negative axis values; Figure $2 \mathrm{a}$ ). This axis explained $42 \%$ of the trait variance and was positively related to $\mathrm{HMax}(r=.77 ; p<.001)$ and SLA $(r=.75$; $p<.001)$ and negatively (albeit weakly) related to WD $(r=-.31$; $p=.001$ ) (Figure 2). The second principal component separated the two savannas (positive and negative score values for Neotropical and Afrotropical savannas, respectively; Figure 2). This second axis explained $33 \%$ of the trait variability and was strongly and negatively correlated with WD $(r=-0.95 ; p<.001)$ and weakly with SLA $(r=$ $-.25 ; p=.002$ ). The third axis, which explained $25 \%$ of trait variation, somehow separated the two Afrotropical forests (Figure $2 \mathrm{~b}$ ) and was negatively correlated with $\mathrm{HMax}(r=-.62 ; p<.001)$ and positively correlated with SLA $(r=.61 ; p<.001)$. Overall, these results were consistent with those obtained when the functional traits were analysed separately (Figure 1), suggesting that this subset of species was representative of their groups.

Based on the list of species with available data for the continuous traits (2,435 species), we searched for data on spinescence in flora 

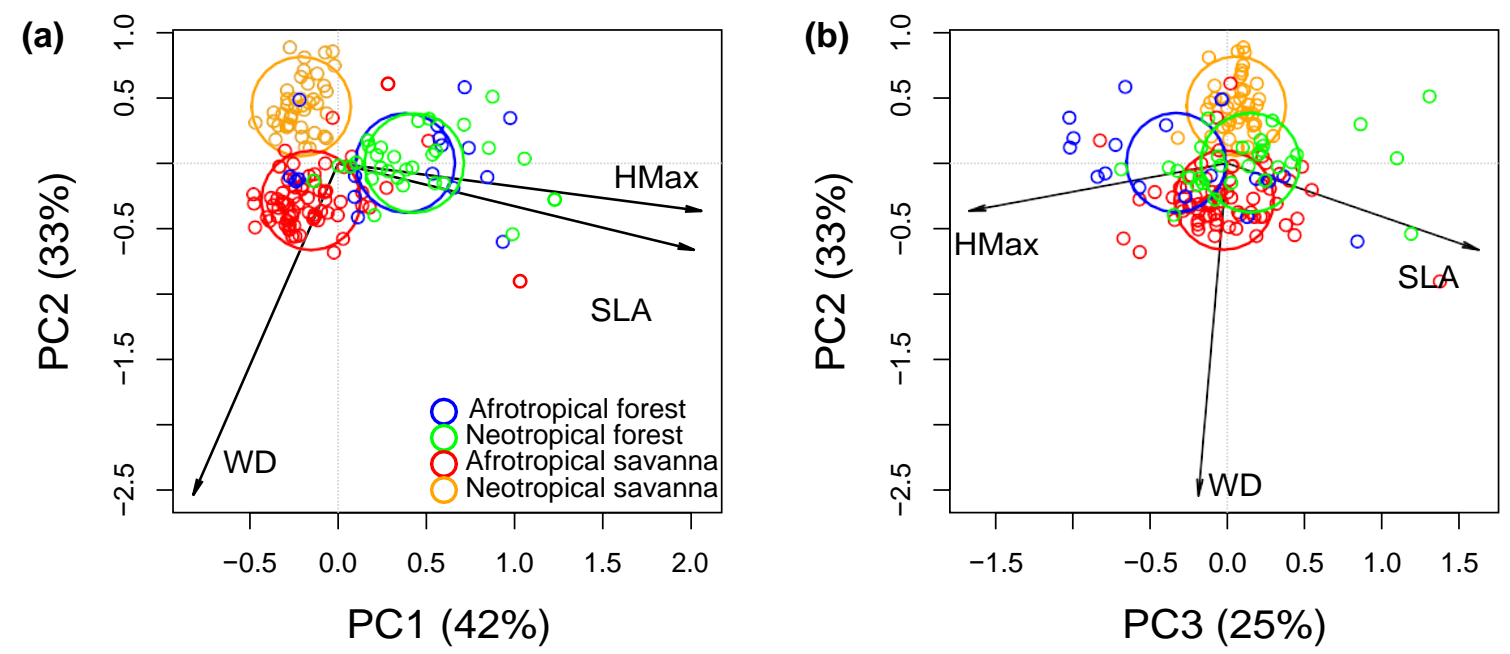

FI G U R E 2 Ordination (principal components analysis) of species and traits showing the occupation of functional space by Afrotropical and Neotropical forest (blue and green, respectively) and savanna (red and orange, respectively) species, based on the subset of species with a complete trait set. (a) Shows the first and second, and (b) the second and third dimensions. Circles are centred on the means for each biome-continent combination. HMax = maximum tree height; PC = principal component; SLA = specific leaf area; WD = wood density [Colour figure can be viewed at wileyonlinelibrary.com]

TA B L E 3 Results of $\chi^{2}$ comparison for the proportion of species with spines and the proportion of geoxylic species among biome-region combinations

\begin{tabular}{|c|c|c|c|c|c|c|c|}
\hline \multirow[b]{2}{*}{ Trait } & \multirow[b]{2}{*}{ Biome } & \multirow[b]{2}{*}{ Region } & \multirow{2}{*}{$\begin{array}{l}\text { Percentage of } \\
\text { species }\end{array}$} & \multicolumn{2}{|l|}{ Savanna } & \multicolumn{2}{|l|}{ Forest } \\
\hline & & & & Afrotropics & Neotropics & Afrotropics & Neotropics \\
\hline \multirow{2}{*}{ Spines } & Savanna & Neotropics & 4.0 & 50.32 & - & 1 & 1 \\
\hline & Forest & Afrotropics & 5.0 & 58.60 & 0.04 & - & 0.968 \\
\hline Geoxylic & Savanna & Neotropics & 10.4 & 55.81 & - & - & - \\
\hline
\end{tabular}

Note: The $\chi^{2}$ statistics are presented below and $p$-values above the diagonal in the last four columns. In the spinescence analyses, $p$-values were adjusted using the Benjamini-Hochberg method for multiple comparisons. The numbers of spinescent and geoxylic species per biome and region in presented in Table 1.

databases for Afrotropical and Neotropical savanna and forest (for details, see methods in Supporting Information Appendix S1). We found reliable information for 1,411 species (Table 1). Afrotropical savanna species showed the highest number of species with spines (34\% of the species), and this was significantly higher than the number of spiny species in all the other groups ( $<5 \%$ in Neotropical savannas and the two forests; Table 3).

We also compared the proportion of geoxyles in two large savanna-dominated regions (Table 3), the Zambeziam region, including 12 African countries (Maurin et al., 2014), and the Brazilian Cerrado region in South America (from different data sources; see Supporting Information Appendix S1). The results suggested that c. $4 \%$ of the woody plants were geoxyles in the Zambeziam region and c. $10 \%$ in the Cerrado (Table 1). As predicted, we found geoxyles to be significantly more common in the Neotropics than in the Afrotropics (see Tables 1 and 3).
Overall, these results were consistent with our predictions for an effect of megafauna in selecting for more herbivory-adapted species in African savannas (more spines and high WD) and for more resourceconservative (although not extremely) and fire-adapted species in Neotropical savannas (more geoxyles and low WD). Moreover, the lower height of Neotropical species is consistent with our predictions for the effect of lower large-fruited seed disperser diversity in the Neotropics.

\section{ENVIRONMENT DOE S NOT E XPL AIN DIFFERENCES IN TRAITS AMONG BIOMES AND CONTINENTS}

Given that variation in SLA, WD and HMax are often attributed to climate, soil and fire, we investigated the extent to which these 
drivers accounted for the biogeographical patterns in these traits. To test this, we used the same analyses as those used to evaluate the relationships of traits with biome and continent (mixed-effect models), but replacing the former explanatory variables by these habitat variables (Partial Model 2; Table2).

Habitat variables were obtained by searching for species occurrence data in GBIF.org (28 February 2020; see reference list for the https://doi.org/10.15468/dl.pxxewu), associating the obtained geographical coordinates with global climate, soil and fire datasets (for methods, see Supporting Information Appendix S1) and calculating their means for each species and variable. Given that many of the climate and soil variables were correlated, we first ran a PCA on the mean values of variables per species to reduce variable dimensionality and selected the axes explaining $>10 \%$ of the variance in climate and soil (the first three in all cases; Table S2.3). These axes were added to the models as explanatory variables along with the fire variables (fire frequency and intensity; for details, see Supporting Information Appendix S1).

In general, savanna species tended to occur in drier and more seasonal climates, where fire frequency, intensity and soil $\mathrm{pH}$ were higher and soil organic carbon content lower compared with forests (Supporting I nformation Appendix S3 and Figure S3.2). High-SLA species tended to be those inhabiting wet and less seasonal areas, with carbon-rich, sand-poor soils and low fire frequency (Table 2, Partial Model 2; Supporting Information Table S2.3). However, these effects were modest, especially in comparison to the effect of biome (Table 2, Partial Model 1). Species with high WD were generally those inhabiting soils with low precipitation and cation exchange capacity and high temperature and $\mathrm{pH}$. This effect was similar in strength to that of biome and biome-region interaction (Table 2). Finally, tall species also inhabited wetter, warmer, less seasonal environments, with fine-textured and cation-poor soils, experiencing low fire intensities.

To assess whether differences between biomes and continents changed after accounting for habitat variables, we repeated these analyses with a full model (biome, continent, their interaction and habitat variables) as the initial model in the backward model selection procedure. If the relationships detected in the Partial Model 1 disappeared (biome and region as predictors), we interpreted as if their effects were accounted for by the environmental variables selected (PCA axes and/or fire variables). Otherwise, we compared the patterns with the predictions for our hypothesis of a direct modulation by megafauna. Overall, including environmental variables in the model with biome and region did not change the biogeographical patterns in the traits (full model in Table 2). However, after accounting for the environment, Afrotropical and Neotropical forests became marginally different in $\operatorname{HMax}(p=.06$; shorter plants in the latter). Wood density became negatively related to water availability (Table 2). Moreover, the SLA values of Neotropical savanna species became only marginally different from those of Afrotropical forest species $(p=.08)$ when differences in soil cations were taken into account (Figure 1a). For all traits, models including both biome and environmental variables and, for WD and HMax, also region and the interactions, showed the lowest AICs. The results support the idea that the biogeographical patterns in the continuous traits are not explained by environmental variables.

\section{TR AIT-ENVIRONMENT RELATIONSHIPS DIFFER BE T WEEN BIOME S AND CONTINENTS}

We also evaluated biome- or continent-specific trait-environmentfire relationships. Differences in these relationships among biomes and continents were interpreted as evidence of the effect of history in modulating trait-environment relationships. Trait-environment relationships, and the strength of the relationships, differed between biomes and regions (Supporting Information Table S2.4). Relationships were generally stronger for savannas than for forests (except for SLA; Supporting Information Table S2.4). We also observed that the variance explained by environmental variables in the savanna-only model for WD was relatively high (20\%; fixed factors alone). To see whether these effects explained the biogeographical differences when including only the savannas, we repeated the backward selection, including "region" among the explanatory variables. The final model kept region (highly significant) among the predictors, and the variance explained by the fixed factors in the model increased to $60 \%$, with region alone explaining $51 \%$ of the variance, along with fire frequency (negative relationship) and the third PCA axis (positively), related mostly to soil clay content $(r=.80)$ and, to a lesser extent, to mean annual temperature $(r=-0.48)$. However, the variance explained by fire frequency and clay alone in the model was negligible $(<1 \%)$, suggesting that WD responds differently to these variables in different regions (different intercepts). Moreover, in this model, the initial (before including "region") relationship with water availability (negative) and cation exchange capacity (positive) disappeared, suggesting that differences in savanna between regions are explained, at least in part, by differences in climate and soil.

\section{DISCUSSION}

Forest and savannas differed consistently between biogeographical regions in traits such as SLA and HMax (both lower in savannas). Nonetheless, savannas of the two continents contrasted in important ways.

First, Afrotropical savanna species presented higher WD. Wood density was previously shown to be related to soil and climate, increasing with temperature (and related variables, such as evapotranspiration; Swenson \& Enquist, 2007) and decreasing with soil fertility (Quesada et al., 2012). We found similar associations (see Table 2; Supporting Information Table S2.3), but these effects did not explain the biogeographical patterns reported here. In fact, we found that savanna and forest, and savannas from different regions, differed in how WD related to these variables (Supporting Information Table S2.4). A high WD confers mechanical resistance to plant stems and branches, and thus, it is important for plants 
submitted to intense browsing by megaherbivores. We suggest that the selective role of disturbance by megafauna explains these differences. To our knowledge, this is the first study to suggest that WD is under selection by megaherbivores.

Second, we found Afrotropical savanna to present more thorny species than Neotropical savanna and forests from the two regions. Spines are an important adaptation to reduce browsing, and Afrotropical spiny species evolved in close proximity to the diversification of bovid herbivores (Charles-Dominique et al., 2016).

Third, the proportion of geoxyle species was lower in the Afrotropics than in the Neotropics. This is a growth form that represents an important adaptation to resist fire (Pausas et al., 2018) and marks the origin of fire-dominated mesic savannas (Maurin et al., 2014; Pennington \& Hughes, 2014; Simon et al., 2009). Ours is the first study to provide evidence that differential patterns of megafauna history shape the distribution of high-WD, thorny and geoxyle plant species at the global scale. Combined with previously reported differences in relative height and bark allocation (Dantas \& Pausas, 2013), these results indicate the importance of megafauna biogeography to understanding of plant trait variation in savannas (Figure 3).

We found a consistent intercontinental difference in HMax across

biomes (Figure 1; Table 2). We did not interpret this pattern as a direct result of disturbance by megaherbivores, because empirical evidence that large mammals, such as elephants, substantially affect tree demography in forest is equivocal (Cardoso et al., 2019; Omeja et al., 2014). Instead, because fruit size and HMax are positively correlated (Wright et al., 2007), the height differentiation shown here is more consistent with a reduced Neotropical stock and distribution

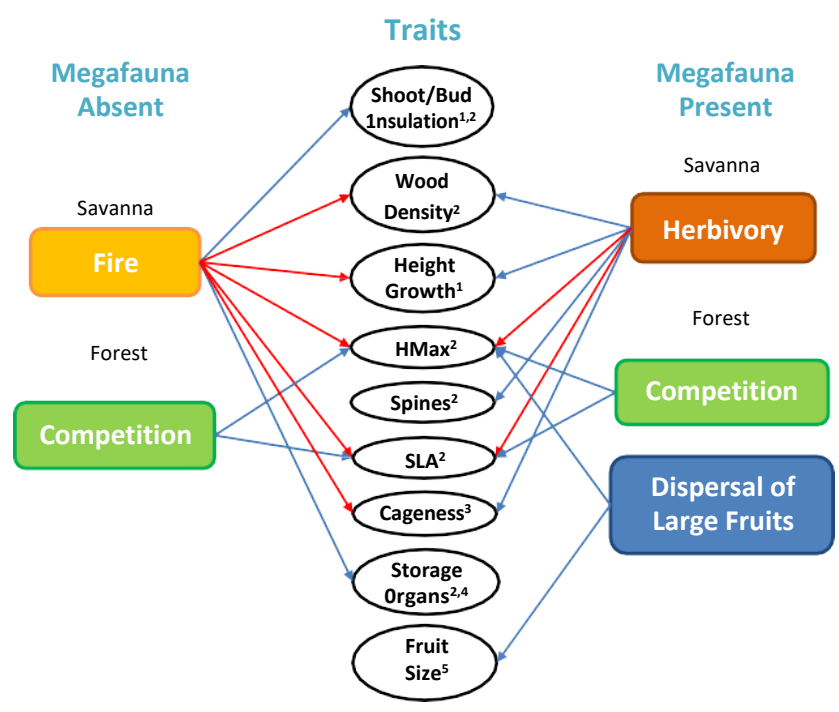

FI G U R E 3 Simplified summary of the effects of megafauna history on plant functional traits of tropical woody species. Arrows between the dominant driver(s) (boxes) and traits (ellipses) indicate positive (blue) and negative (red) effects. Numbers (superscripts) in traits refer to the sources for the information: (1) Dantas and Pausas (2013); (2) present study; (3) Archibald and Bond (2003) and Staver et al. (2012); (4) Tomlinson et al. (2012); and (5) Mack (1993), Guimarães et al. (2008) and Doughty, Wolf, et al. (2016) [Colour figure can be viewed at wileyonlinelibrary.com] of large-fruited plants owing to the extinction and lower pre-extinction historical diversity of megadispersers (Figure 3). This interpretation is consistent with evidence that large-fruited trees are more common in Afrotropical than Neotropical forest taxa (Mack, 1993) and that the distribution of species with megafauna-dispersed fruits has probably reduced since the extinction of megafauna (Doughty, Wolf, et al., 2016). However, HMax differed only marginally between the two forests, which suggests that differences in megafauna abundance before the Holocene extinction might have played a role. Given that HMax is correlated with multiple traits and functions (Liu et al., 2019; Moles et al., 2009), we suggest that more studies should be carried out to understand the underlying causes of this intercontinental difference fully.

We did not find clear evidence of megafauna biogeography shaping SLA. Although SLA was lower in savannas, both savannas had similar SLA values (Figure 1). The lower SLA in savannas than in forests might result from a common and indirect effect of both fire and herbivory in savannas (i.e., canopy openness). In fact, SLA is a very plastic trait that responds readily to small variations in light incidence (e.g., similar light environments may even produce overlaps between the SLA values of savanna and forest species; Hoffmann \& Franco, 2003).

The extinct megafauna of South America included a high diversity of large browsers (Owen-Smith, 2013), which suggests that woody plants were also subject to herbivory selection on that continent by the time these species evolved. However, evidence indicates that, if South American large mammals had not gone extinct, their distribution would be concentrated in southern, southeastern and eastern portions of the continent (see Doughty, Faurby, \& Svenning, 2016: fig. 5a). In tropical and subtropical latitudes, these areas would coincide, in part, with the south-eastern distribution of modern tropical savannas of the Cerrado region but would mostly overlap with regions dominated by seasonally dry forests (SDF; e.g., Gran Chaco and Caatinga regions) and humid subtropical grasslandforest mosaics (SGFM). Modern Neotropical savanna species, with their weak and vulnerable stems (low relative height growth, low WD and lack of spines), are unlikely to have evolved in regions with abundant browsers. In fact, ecosystems with similar climate and soil conditions currently exist in tropical Africa (Supporting Information Figure S3.2) but are avoided by large mammals, which generally prefer conditions similar to those of Neotropical SDF (i.e., dry and seasonal climates, high soil fertility; Dantas et al., 2016; Dexter et al., 2018). A quick search for information on spinescence for 200 randomly selected Neotropical SDF species (100 deciduous forest and 100 semi-arid thorny woodland species) from Oliveira-Filho (2017) showed that the proportion of spinescent species in SDF is similar $(23 \% ; n=60)$ to that of Afrotropical savannas $\left(\chi^{2}=1.67 ; p=.196\right)$ and much higher than that of Neotropical savannas $\left(\chi^{2}=20.14 ; p<.001\right)$. The SGFM, in contrast, occur in moister climates. Evidence suggests that grasslands in these mosaics are experiencing encroachment by moist forest and depend on anthropogenic intervention (fire and grazing) to prevent complete replacement by moist forest (Overbeck 
et al., 2007). Although some authors attribute this process to climate change, large mammalian herbivores could have developed a role in maintaining these grasslands before human arrival. This is consistent with fossil evidence that before extinction of the megafauna, SGFM grassland species dominated in Neotropical areas now occupied by modern tropical savanna (Behling, 2002). Moreover, increased fire frequency in the SGFM region coincided with the period of megafauna extinction (Overbeck et al., 2007), which is consistent with studies showing that large grazers inhibit fire in Africa (Dantas et al., 2016). Finally, the grasslands in these mosaics have high floristic affinity with Chacoan SDF (but not with modern tropical savannas; Overbeck et al., 2007), despite occuring in moister climates. Thus, the Neotropical home of South American extinct megafauna was probably a more open version (probably savanna like) of SDF, very similar to the vegetation dominating in modern semi-arid African savannas, in addition to moister, non-seasonal grasslands, most of which were dominated by Chaco-related plant species. With the extinction of the megafauna, these ecosystems tended to be replaced by forest and woodlands lacking substantial grass cover or by fire-maintained savannas, depending on the climate, soil and fire frequency; in other cases, these ecosystems persisted owing to human intervention (landscape anachronism; Pausas \& Bond, 2020).

Although trait relationships with the environment were similar to those in previous studies (Liu et al., 2019; Maire et al., 2015; Moles et al., 2009; Ordoñez et al., 2009; Quesada et al., 2012; Reich et al., 2007; Swenson \& Enquist, 2007), the variance explained was somewhat low. Disturbance-maintained savannas are often poorly represented in studies on trait-environment relationships at broad spatial scales. Moreover, savanna and forest assemblages, and even savanna assemblages from different regions, differ in their trait-environment relationships (Supporting Information Table S2.4). For instance, in savannas, WD was positively related to the second resource-related PCA axes, whereas in forests, WD was negatively related to this axis (Supporting Information Table S2.4). Finally, global studies often omit random effects resulting from context dependence (e.g., unmeasured conditions, methodological differences), which can substantially impact the results. For instance, for SLA, the same variables that explained $20 \%$ of variance in the best linear mixed-effectmodel (Table 3) would explain $45 \%$ if we used a multiple linear regression model $\left(R^{2}{ }_{\text {adj }}=.45 ; p<.001\right)$. Thus, our current understanding of traitenvironment relationships might be biased towards infrequently disturbed biomes and by poor statistical analyses.

We showed that biome and regional differences in key functional traits in the tropics are better explained by disturbance than by species environmental preferences. Modern Neotropical and Afrotropical savannas and tropical forest species probably evolved under different disturbance regimens, resulting in dif- ferent evolutionary responses to environment and disturbance gradients. After megaherbivores went extinct in South America, savannas probably became more restricted to seasonal, relatively high-rainfall climates, in which fire intensity is sufficiently high to maintain these ecosystems. This must have boosted the already high fire intensity resulting from the historical lower amounts of grazer species. Thus, in the Neotropics, successful woody savanna plants are those that maximize fire resistance and recovery (stem and bud protection, with inexpensive light stems). In Africa, plants having similar strategies are probably restricted geographically, and the strong and persistent megaherbivore control fa- vours plants that evolved to maximize herbivory resistance and fire avoidance (high WD, early allocation to height and numerous spines). The extinction of megadispersers in the Neotropics could have maximized the intercontinental distinctions by promoting height and fruit size asymmetry.

Overall, our results support the idea that the differential patterns of megafauna history in the tropics are likely to have affected the present biogeographical patterns of plant functional trait variation (Figure 3). Looking at plants and thinking about the megafauna history might provide new insights for understanding the patterns of vegetation across the globe.

\section{ACKNOWLEDGMENTS}

This study was partially financed by the Coordenação de Aperfeiçoamento de Pessoal de Nível Superior (CAPES), Brazil (Finance Code: 001; Project: 88887.311538/2018-00). J.G.P. thanks the FIROTIC project from the Spanish government (PGC2018-096569-B-I00).

\section{DATA AVAIL AB IL IT Y S TATE ME NT}

The data that support the findings of this study are openly available in Dryad at https://doi.org/10.5061/dryad.3xsj3txc0.

\section{ORCID}

Vinicius L. Dantas (iD https://orcid.org/0000-0002-6934-3277

Juli G. Pausas (iD https://orcid.org/0000-0003-3533-5786

\section{R EFER EN C E S}

Archibald, S., \& Bond, W. (2003). Growing tall vs growing wide: Tree architecture and allometry of Acacia karroo in forest, savanna, and arid environments. Oikos, 102, 3-14.

Archibald, S. A., Lehmann, C. E. R., Belcher, C. M., Bond, W. J., Bradstock, R. A., Daniau, A.-L., ... Zanne, A. E. (2018). Biological and geophysical feedbacks with fire in the Earth system. Environmental Research Letters, 13, 033003.

Behling, H. (2002). South and southeast Brazilian grasslands during Late Quaternary times: A synthesis. Palaeogeography, Palaeoclimatology, Palaeoecology, 177, 19-27.

Bond, W. J. (2005). Large parts of the world are brown or black: A different view on the "Green World" hypothesis. Journal of Vegetation Science, 16, 261-266.

Cardoso, A. W., Malhi, Y., Oliveras, I., Lehmann, D., Ndong, J. E., Dimoto, E., ... Abernethy, K. (2019). The role of forest elephants in shaping tropical forest-savanna coexistence. Ecosystems. https://doi. org/10.3389/fevo.2018.00104

Charles-Dominique, T., Davies, T. J., Hempson, G. P., Bezeng, B. S., Daru, B. H., Kabongo, R. M., ... Bond, W. J. (2016). Spiny plants, mammal browsers, and the origin of African savannas. Proceedings of the National Academy of Sciences USA, 113, E5572-E5579.

Chave, J., Coomes, D., J ansen, S., Lewis, S. L., Swenson, N. G., \&Zanne, A. E. (2009). Towards a worldwide wood economics spectrum. Ecology Letters, 12, 351-366. 
Dantas, V. L., Batalha, M. A., \& Pausas, J. G. (2013). Fire drives functional thresholds on the savanna-forest transition. Ecology, 94, 2454-2463.

Dantas, V. L., Hirota, M., Oliveira, R. S., \& Pausas, J. G. (2016). Disturbance maintains alternative biome states. Ecology Letters, 19, 12-19.

Dantas, V. L., \& Pausas, J. G. (2013). The lanky and the corky: Fireescape strategies in savanna woody species. Journal of Ecology, 101, 1265-1272.

Dantas, V. L., \& Pausas, J. G. (2020). Data from: Megafauna biogeography explains plant functional trait variability in the tropics. Dryad, Dataset. https://doi.org/10.5061/dryad.3xsj3txc0

Dexter, K. G., Pennington, R. T., Oliveira-Filho, A. T., Bueno, M. L., Silva de Miranda, P. L., \& Neves, D. M. (2018). Inserting tropical dry forests into the discussion on biome transitions in the tropics. Frontiers in Ecology and Evolution, 6, 104. Retrieved from https://www.front iersin.org/article/10.3389/fevo.2018.00104

Dinerstein, E., Olson, D., Joshi, A., Vynne, C., Burgess, N. D., Wikramanayake, E., ... Saleem, M. (2017). An ecoregion-based approach to protecting half the terrestrial realm. Bioscience, 67, 534545.

Doughty, C. E. (2017). Herbivores increase the global availability of nutrients over millions of years. Nature Ecology and Evolution, 1, 18201827.

Doughty, C. E., Faurby, S., \& Svenning, J. C. (2016). The impact of the megafauna extinctions on savanna woody cover in South America. Ecography, 39, 213-222.

Doughty, C. E., Wolf, A., Morueta-Holme, N., Jørgensen, P. M., Sandel, B., Violle, C., ... Galetti, M. (2016). Megafauna extinction, tree species range reduction, and carbon storage in Amazonian forests. Ecography, 39, 194-203.

GBIF.org. (2020, February 28) GBIF occurrence download. https://doi. org/10.15468/dl.pxxewu.

Guimarães, P. R., Galetti, M., \&J ordano, P. (2008). Seed dispersal anachronisms: Rethinking the fruits extinct megafauna ate. PLOS ONE, 3, e1745.

Hietz, P., Rosner, S., Hietz-Seifert, U., \& Wright, S. J. (2017). Wood traits related to size and life history of trees in a Panamanian rainforest. New Phytologist, 213, 170-180.

Hoffmann, W. A., \& Franco, A. C. (2003). Comparative growth analysis of tropical forest and savanna woody plants using phylogenetically independent contrasts. Journal of Ecology, 91, 475-484.

Lehmann, C. E. R., Anderson, T. M., Sankaran, M., Higgins, S. I., Archibald, S., Hoffmann, W. A., ... Bond, W. J. (2014). Savanna vegetation-fire-climate relationships differ among continents. Science, 343, 548-552.

Liu, H., Gleason, S. M., Hao, G., Hua, L., He, P., Goldstein, G., \& Ye, Q. (2019). Hydraulic traits are coordinated with maximum plant height at the global scale. Science Advances, 5, eaav1332.

Mack, A. L. (1993). The sizes of vertebrate-dispersed fruits: A NeotropicalPaleotropical comparison. The American Naturalist, 142, 840-856.

Maire, V., Wright, I. J., Prentice, I. C., Batjes, N. H., Bhaskar, R., van Bodegom, P. M., ... Santiago, L. S. (2015). Global effects of soil and climate on leaf photosynthetic traits and rates. Global Ecology and Biogeography, 24, 706-717.

Maurin, O., Davies, T. J., Burrows, J. E., Daru, B. H., Yessoufou, K., Muasya, A. M., ... Bond, W. J. (2014). Savanna fire and the ori- gins of the "underground forests" of Africa. New Phytologist, 204, 201214.

Moles, A. T., Warton, D. I., Warman, L., Swenson, N. G., Laffan, S. W., Zanne, A. E., ... Leishman, M. R. (2009). Global patterns in plant height. Journal of Ecology, 97, 923-932.

Moncrieff, G. R., Bond, W. J., \& Higgins, S. I. (2016). Revising the biome concept for understanding and predicting global change impacts. Journal of Biogeography, 43, 863-873.

Oliveira-Filho, A. T. (2017). NeoTropTree, Flora arbórea da Região Neotropical: Um banco de dados envolvendo biogeografia, diversidade e conservação. Universidade Federal de Minas Gerais. http://www. neotroptree.info

Omeja, P. A., Jacob, A. L., Lawes, M. J., Lwanga, J. S., Rothman, J. M., Tumwesigye, C., \& Chapman, C. A. (2014). Changes in elephant abundance affect forest composition or regeneration? Biotropica, 46, 704711.

Ordoñez, J. C., Van Bodegom, P. M., Witte, J. P. M., Wright, I. J., Reich, P. B., \& Aerts, R. (2009). A global study of relationships between leaf traits, climate and soil measures of nutrient fertility. Global Ecology and Biogeography, 18, 137-149.

Overbeck, G., Muller, S., Fidelis, A., Pfadenhauer, J., Pillar, V., Blanco, C., ... Forneck, E. (2007). Brazil's neglected biome: The South Brazilian Campos. Perspectives in Plant Ecology, Evolution and Systematics, 9, 101-116.

Owen-Smith, N. (2013). Contrasts in the large herbivore faunas of the southern continents in the late Pleistocene and the ecological implications for human origins. Journal of Biogeography, 40, 1215-1224.

Pausas, J. G., \& Bond, W. J. (2020). Alternative biome states in terrestrial ecosystems. Trends in Plant Science, 25, 250-263.

Pausas, J. G., Keeley, J. E., \& Schwilk, D. W. (2017). Flammability as an ecological and evolutionary driver. Journal of Ecology, 105, 289-297.

Pausas, J. G., Lamont, B. B., Paula, S., Appezzato-da-Glória, B., \& Fidelis, A. (2018). Unearthing belowground bud banks in fire-prone ecosystems. New Phytologist, 217, 1435-1448.

Pellegrini, A. F. A., Pringle, R. M., Govender, N., \& Hedin, L. O. (2016). Woody plant biomass and carbon exchange depend on elephant-fire interactions across a productivity gradient in African savanna. Journal of Ecology, 105, 111-121.

Pennington, R. T., \& Hughes, C. E. (2014). The remarkable congruence of New and Old World savanna origins. New Phytologist, 204, 4-6.

Poorter, H., Niinemets, Ü., Poorter, L., Wright, I. J ., \& Villar, R. (2009). Causes and consequences of variation in leaf mass per area (LMA): A meta-analysis. New Phytologist, 182, 565-588.

Quesada, C. A., Phillips, O. L., Schwarz, M., Czimczik, C. I., Baker, T. R., Patiño, S., ... Lloyd, J. (2012). Basin-wide variations in Amazon forest structure and function are mediated by both soils and climate. Biogeosciences, 9, 2203-2246.

Reich, P. B., Wright, I. J., \& Lusk, C. H. (2007). Predicting leaf physiology from simple plant and climate attributes. Ecology, 17, 1982-1988.

Rogers, B. M., Soja, A. J., Goulden, M. L., \& Randerson, J. T. (2015). Influence of tree species on continental differences in boreal fires and climate feedbacks. Nature Geoscience, 8, 228-234.

Simon, M. F., Grether, R., de Queiroz, L. P., Skema, C., Pennington, R. T., \& Hughes, C. E. (2009). Recent assembly of the Cerrado, a neotropical plant diversity hotspot, by in situ evolution of adaptations to fire. Proceedings of the National Academy of Sciences USA, 106, 20359-20364.

Staver, A. C., Bond, W. J., Cramer, M. D., \& Wakeling, J. L. (2012). Topdown determinants of niche structure and adaptation among African Acacias. Ecology Letters, 15, 673-679.

Swenson, N. G., \& Enquist, B. J. E. (2007). Ecologial and evolutionary determinants of a key plant functional trait: Wood density and its community-wide variation across latitude and elevation. American Journal of Botany, 94, 451-459.

Tomlinson, K. W., Sterck, F. J., Bongers, F., da Silva, D. A., Barbosa, E. R. M., Ward, D., ... van Langevelde, F. (2012). Biomass partitioning and root morphology of savanna trees across a water gradient. Journal of Ecology, 100, 1113-1121.

Westoby, M., Falster, D. S., Moles, A. T., Vesk, P. A., \& Wright, I. J. (2002). Plant ecological strategies: Some leading dimensions of variation between species. Annual Review of Ecology and Systematics, 33, 125-159.

Wright, I. J., Ackerly, D. D., Bongers, F., Harms, K. E., Ibarra-Manriquez, G., Martinez-Ramos, M., ... Wright, S. J. (2007). Relationships among ecologically important dimensions of plant trait variation in seven neotropical forests. Annals of Botany, 99, 1003-1015. 


\section{APPENDIX}

\section{DATA S OURCE S FOR FUNC TIONAL TR AIT DATA}

Abbot, P., Lowore, J., Khofi, C. \& Werren, M. (1997). Defining firewood quality: A comparison of quantitative and rapid appraisal techniques to evaluate firewood species from a Southern African Savanna. Biomass and Bioenergy, 12, 429-437.

Abe, N., Miatto, R. C. \& Batalha, M. A. (2018). Relationships among functional traits define primary strategies in woody species of the Brazilian 'cerrado'. Revista Brasileira de Botanica, 41, 351-360.

African Plant Database (v.3.4.0). Conservatoire et J ardin botaniques de la Ville de Genève and South African National Biodiversity Institute, Pretoria. Retrieved from http://www.ville-ge.ch/musinfo/bd/cjb/ africa/

Balch, J. K., Nepstad, D. C., Curran, L. M., Brando, P. M., Portela, O., Guilherme, P., ... de Carvalho, O. (2011). Size, species, and fire behavior predict tree and liana mortality from experimental burns in the Brazilian Amazon. Forest Ecology and Management, 261, 68-77.

Barbosa, R. I., \& Fearnside, P. M. (2004). Wood density of trees in open savannas of the Brazilian Amazon. Forest Ecology and Management, 199, 115-123.

Batalha, M. A., Silva, I. A., Cianciaruso, M. V., França, H., \& de Carvalho, G. H. (2011). Phylogeny, traits, environment, and space in cerrado plant communities at Emas National Park (Brazil). Flora-Morphology, Distribution, Functional Ecology of Plants, 206, 949-956.

Borchert, R. (1994). Soil and stem water storage determine phenology and distribution of tropical dry forest trees. Ecology, 75, 1437-1449.

Bucci, S. J., Goldstein, G., Meinzer, F. C., Scholz, F. G., Franco, A. C., \& Bustamante, M. (2004). Functional convergence in hydraulic architecture and water relations of tropical savanna trees: From leaf to whole plant. Tree Physiology, 24, 891-899.

Bucci, S. J., Scholz, F. G., Goldstein, G., Meinzer, F. C., Franco, A. C., Campanello, P. I., ... Miralles-Wilhelm, F. (2006). Nutrient availability constrains the hydraulic architecture and water relations of savannah trees. Plant, Cell \& Environment, 29, 2153-2167.

Cianciaruso, M. V., Silva, I. A., Manica, L. T., \& Souza, J. P. (2013). Leaf habit does not predict leaf functional traits in cerrado woody species. Basic and Applied Ecology, 14, 404-412.

Costa, T. G., Bianchi, M. L., de Protásio, T. P., Trugilho, P. F., \& Pereira, A. J. (2014). Wood quality of five species from cerrado for production of charcoal. Cerne, 20, 37-45.

Dantas, V. L., \& Batalha, M. A. (2012). Can antiherbivory resistance explain the abundance of woody species in a Neotropical savanna? Botany, 90, 93-99.

Dantas, V. L., Batalha, M. A., \& Pausas, J. G. (2013). Fire drives functional thresholds on the savanna-forest transition. Ecology, 94, 2454-2463.

Domingues, T. F., Meir, P., Feldpausch, T. R., Saiz, G., Veenendaal, E. M., Schrodt, F., ... Lloyd, J. (2010). Co-limitation of photosynthetic capacity by nitrogen and phosphorus in West Africa woodlands. Plant, Cell and Environment, 33, 959-980.

Flora do Brasil (2020) [in construction]. Jardim Botânico do Rio de Janeiro. Retrieved from http://floradobrasil.jbrj.gov.br/

Hao, G. Y., Hoffmann, W. A., Scholz, F. G., Bucci, S. J., Meinzer, F. C., Franco, A. C., ... Goldstein, G. (2008). Stem and leaf hydraulics of congeneric tree species from adjacent tropical savanna and forest ecosystems. Oecologia, 155, 405-415.

Higgins, S. I., Bond, W. J., Combrink, H., Craine, J. M., February, E. C., Govender, N., ... Trollope, W. S. W. (2012). Which traits determine shifts in the abundance of tree species in a fire-prone savanna? Journal of Ecology, 100, 1400-1410.

Kitajima, K., \& Poorter, L. (2010). Tissue-level leaf toughness, but not lamina thickness, predicts sapling leaf lifespan and shade tolerance of tropical tree species. New Phytologist, 186, 708-721.

Markesteijn, L., \& Poorter, L. (2009). Seedling root morphology and biomass allocation of 62 tropical tree species in relation to drought- and shade-tolerance. Journal of Ecology, 97, 311-325.

Markesteijn, L., Poorter, L., Paz, H., Sack, L., \& Bongers, F. (2011). Ecological differentiation in xylem cavitation resistance is associated with stem and leaf structural traits. Plant, Cell and Environment, 34, 137-148.

Meir, P., Levy, P. E., Grace, J., \& Jarvis, P. G. (2007). Photosynthetic parameters from two contrasting woody vegetation types in West Africa. Plant Ecology, 192, 277-287.

Miatto, R. C. (2011). A inclusão da abundância na diversidade funcional aumenta o seu poder de previsão?: teste em uma comunidade de cerrado (Master's dissertation). São Carlos, SP: UFSCar.

Miatto, R. C., Wright, I. J ., \& Batalha, M. A. (2016). Relationships between soil nutrient status and nutrient-related leaf traits in Brazilian cerrado and seasonal forest communities. Plant and Soil, 404, 13-33.

Nygard, R., \& Elfving, B. (2000). Stem basic density and bark proportion of 45 woody species in young savanna coppice forests in Burkina Faso. Annals of Forest Science, 57, 143-153.

Oliveira-Filho, A. T. (2017). NeoTropTree, Flora arbórea da Região Neotropical: Um banco de dados envolvendo biogeografia, diversidade e conservação. Universidade Federal de Minas Gerais. http://www. neotroptree.info

Poorter, L., McDonald, I., Alarcón, A., Fichtler, E., Licona, J.-C., PeñaCarlos, M., ... Sass-Klaassen, U. (2010). The importance of wood traits and hydraulic conductance for the performance and life history strategies of 42 rainforest tree species. New Phytologist, 185, 481-492.

Ribeiro, S. C., Fehrmann, L., Soares, C. P. B., J Jacovine, L. A. G., Kleinn, C., $\&$ de Oliveira Gaspar, R. (2011). Above- and belowground biomass in a Brazilian Cerrado. Forest Ecology and Management, 262, 491-499.

Santiago, L. S., Goldstein, G., Meinzer, F. C., Fisher, J. B., Machado, K., Woodruff, D., \& Jones, T. (2004). Leaf photosynthetic traits scale with hydraulic conductivity and wood density in Panamanian forest canopy trees. Oecologia, 140, 543-450. 
Scogings, P. F., Taylor, R. W., \& Ward, D. (2012). Inter- and intra-plant variations in nitrogen, tannins and shoot growth of Sclerocarya birrea browsed by elephants. Plant Ecology, 213, 483-491.

Vale, A. T., Dias, I. S., \& Santana, M. A. E. (2010). Relações entre propriedades químicas, físicas e energéticas da madeira em cinco espécies de cerrado. Ciênc ia Florestal, 20, 137-145.

van der Plas, F., Howison, R., Reinders, J., Fokkema, W. \& Olff, H. (2013). Functional traits of trees on and off termite mounds: Understanding the origin of biotically-driven heterogeneity in savannas. Journal of Vegetation Science, 24, 227-238.

Vinya, R., Malhi, Y., Brown, N., \& Fisher, J. B. (2012). Functional coordination between branch hydraulic properties and leaf functional traits in miombo woodlands: Implications for water stress management and species habitat preference. Acta Physiologiae Plantarum, 34, 1701-1710.

Yeaton, R. (1988). Porcupines, fires and the dynamics of the tree layer of the Burkea Africana Savanna. Journal of Ecology, 76, 1017-1029.

Zanne, A. E., Lopez-Gonzalez, G., Coomes, D. A., Ilic, J., J ansen, S., Lewis, S. L., ... Chave, J. (2009). Global wood density database. Dryad. Retrieved from http://hdl.handle.net/10255/dryad.235

Zizka, A., Govender, N. \& Higgins, S.I. (2014). How to tell a shrub from a tree: A life-history perspective from a South African savanna. Austral Ecology, 39, 767-778. 